\title{
DEVELOPMENT OF «SOFT SKILLS» DURING ESL COURSE FOR BUSINESS STUDENTS
}

Rapid economic and social-cultural development of the society and transition to new models of business activities necessitate the formation of «soft skills» of future specialists. Modern labor market requires highly-qualified professionals who are ready for on-going self-development and advancement, who are team players, communicative, flexible, computerliterate, etc. It is noted that the course of English as a Second Language (ESL) has a great potential for the formation of «soft skills» related to effective participation in intercultural professional communication and personal development. The author's vision of the structure of interrelations between "soft skills» and school background, teacher's competence and efforts, student's environment, technical strengths and hard work is presented. Four basic types of «soft skills» are distinguished. The division of soft skills into four main areas is offered. The skills that can be successfully developed when teaching ESL to business students through mutual projects, team work, the need to solve the tasks and constantly interact with partners are identified. It is stated that development of «soft skills» among students of universities can be based on support program (academic focused and non-academic programs), formal teaching and learning and campus life. It is established that implementation of the methodology of formation of «soft skills» should be based on the principles of communicative, intercultural, professional, individualized and socio-emotionally oriented learning, interdisciplinary links, etc. The stages of the technology of formation of «soft skills» when teaching ESL providing a step-by-step construction of the learning process have been established. Possible ways of introducing «soft skills» in ESL course are clarified. Based on the research, key qualities of a teacher having «soft skills» who teaches ELS to business students there have been identified. Therefore, it is recommended to implement «soft skills» development as an integral component of the ESL course.

Key words: «soft skills», development, English as a second language, business students.

Лариса ДОВГАНЬ, orcid.org/0000-0003-4742-6570 кандидат педагогічних наук, дочент, доиент кафедри іноземної філології та перекладу Вінницького торговельно-економічного інституту

Київського начіонального торговельно-економічного університету (Вінниия, Україна) laradovhan@ukr.net

\section{РОЗВИТОК «SОFT SKILLS» ПРИ ВИВЧЕННІ КУРСУ «АНГЛІЙСЬКА ЯК ДРУГА МОВА»У СТУДЕНТІВ ЕКОНОМІЧНИХ СПЕЦІАЛЬНОСТЕЙ}

Швидкий економічний та сочіально-культурний розвиток суспільства, перехід до нових моделей підприємнищької діяльності зумовлює необхідність формування «soft skills» майбутніх спеціалістів. Сучасний ринок праці вимагає висококваліфікованих фахівиів, готових до постійного саморозвитку та прогресу, командних гравиів, комунікативних, гнучких, комп 'ютерно грамотних. Зазначається, щчо курс англійської як другої мови має великий потенціал для формування «soft skills», пов 'язаних з ефективною участю в міжкультурному професійному спілкуванні та розвитку особистості. Представлено авторське бачення структури взаємозв'язків між «soft skills» та компетентністю, зусиллями вчителів, оточенням студентів, технічними силами та наполегливою роботою. Виділено чотири основних типи «soft skills». Запропоновано розподіл «soft skills» на чотири основні напрями. Визначені навички, які можна успішно розвивати під час навчання англійської як другої мови для студентів економічних спеціальностей за допомогою спільних проєктів, роботи в команді, необхідності вирішувати спільні завдань та постійної взаємодї з партнерами. Зазначається, щчо розвиток «soft skills» серед студентів університетів може базуватися на програмі підтримки (академічні та неакадемічні програми), формальному навчанні та навчанні тощьо. Встановлено, щзо впровадження методики формування «soft skills» має базуватися на принциипах комунікативного, міжкультурного, професійного, індивідуалізованого, соціально й емоційно орієнтованого 
навчання, міждисциплінарних зв'язків тощзо. Було встановлено етапи технологї̈ формування «soft skills» nid час викладання англійської як другої мови. На основі дослідження було визначено ключові якості викладача, який має «м'які навички» і викладає англійську студентам економічних спеціальностей. Тому рекомендується впроваджувати розвиток «soft skills» як невід’'ємний складник курсу вивчення англійської мови.

Ключові слова: «soft skills», розвиток, англійська як друга мова, студенти економічних спеціальностей.

Introduction. The processes of globalization promote the development of new trends in education, introduction of innovative technologies, alternative teaching forms and methods. At the same time rapid economic and social-cultural development of the society, transition to new models of business activities necessitate the formation of «hard skills» involving professional competences along with «soft skills» of future specialists. Modern labor market requires highly-qualified professionals who are ready for on-going self-development and advancement, who are team players, communicative, flexible, computer-literate, etc.

Foreign language skills are also becoming of great importance under current conditions of European integration and cooperation between nations. English as a language of global communication holds the leading position among the other foreign languages and it is widely used in all types of social communication, including business, scientific and cultural-educational discourses. There, foreign-language competence has become one of essential skills in a globalized world. At the same time, there can still be observed unsatisfactory level of interpersonal, communicative and analytical abilities of high school graduates.

Hence, proficiency in English in such conditions is of particular importance for future professionals in the field of business, especially international. At the same time, the course of English as a Second Language has a great potential for the formation of «soft skills» that are related to effective participation in intercultural professional communication and personal development.

Results and discussion. The issues of soft skills development are widely discussed in the framework of internationalization of education and a single European educational space and appear in the English-language academic discourse when discussing «key competencies», «transversal skills» or «transferable skills».

The term «soft skills» was first used in 1990s in research papers on management and education in the United States and Germany. Robles (2012) defines «soft skills as character traits, attitudes and behaviors rather than technical aptitude or knowledge. Soft skills are intangible, non-technical, personality-specific skills that determine one's strengths as a leader, facilitator, mediator, and negotiator» (Robles, 2012: 457).
Since the late 1990s, use of the term «soft skills» has extended significantly (Collins, 2018) in business training, career advising, and job postings, where it is often equated with «interpersonal» or «people skills».

According to B. Schulz, «the $21^{\text {st }}$ century employers are looking for graduates who possess «soft skills» that include responsibility, self-confidence, social and communication skills, flexibility, team-spiritedness, good work attitude, self-motivation and self-management. Many skills learned through project-based learning are highly appreciated by modern employers including the ability to deal with others, handle interpersonal conflicts, make thoughtful decisions, as well as solve complex problems» (Schulz, 2011: 67).

Researchers from Harvard University, the Carnegie Endowment for International Peace and the Stanford Research Institute have found that $75-85 \%$ of professional success depends on the level of «soft skills» and only $15-25 \%$ depends «hard skills» (knowledge of technical courses and practical skills) (Klaus, 2010; Watts et al., 2008).

The British Association of Graduate Recruiters (AGR) has reported that employers argue many graduates lack «soft skills», e.g. those of team work and «they go on to explain that candidates are normally academically proficient but lacking in "soft skills» such as communication as well as verbal and numerical reasoning» (AGR, 2007). Some researchers have estimated the importance of the interrelationship, at least partly, between English language skills, «soft skills» and economic development and have found «soft skills» to be necessary to fuel faster economic development and (Coughlan, 2015).

«Soft skills» focus more on people than processes. Today's economy and ascendance of work teams puts a new premium on people skills and relationshipbuilding. «soft skills» are indeed essential to recruitment: nearly $90 \%$ of job postings require «soft skills». On average, a job posting requires 4 «soft skills», while $10 \%$ of the job postings require 10 «soft skills» or more (Boostrs, 2020).

Different scientists have studied «soft skills» at different times, and today there are many classifications of «soft skills», which can be divided into four main areas:

1. Basic communication skills that help to develop relationships with people, support a conversation, behave effectively in critical situations. 
2. Self-management skills that help to control time and processes effectively.

3. Effective thinking skills that are managing cognitive processes, which help to make life and work more systematic.

4. Management skills that people need at the stage when they become entrepreneurs and leaders in any business activities.

Examples of «soft skills» are clarified in Table 1.

According to Recruitment Managers and HR Professionals in the USA Most Sought-After «soft skills» include the ones presented in fig. 1 .

Thus, the most important «soft skills» are strong work ethic, positive attitude, self-motivation, being self-motivated and team-oriented. All these skills can be successfully developed when teaching ESL to business students through mutual projects, team work, the need to solve the tasks and constantly interact with the partners, etc.

Development of «soft skills» among students of universities can be based on support program (academic focused and non-academic programs), formal teaching and learning and campus life.

Fundamental «soft skills» are essential for nearly any job as well. Among them there can be distinguished communicative skills (both written and oral), time management, decision-making and judgment, team spirit, adaptability, analytical skills and autonomy.

Employers are looking for employees having such «soft skills» as problem solving and critical think- ing. Their presence and depth are difficult to assess reliably based on a summary and interview. Strong presentation, communication, and English skills are very important in this instance and all of those skills are transferable, but the result of such an interview is ambiguous. However, there is one key skill that can be assessed very accurately, and that is knowledge of English. Communicative skills are among the top five most popular with the employers, and improvement of these skills as well as good command of English increases job opportunities for applicants, especially for young graduates.

We consider that within the ESL course it is necessary to form:

- ability to analyze, synthesize and evaluate data and teaching materials in English;

- respect for the representatives of other cultures, ability to work in a multicultural environment;

- skills of time management and self-discipline that are necessary for self-improvement;

- ability to form one's point of view on a problem and express it in English;

- study the materials and solve the tasks given in English;

- willingness to experiment, desire to solve new communicative problems related to the study of English;

- ability to search for some information in English, understand digital content and use software with English interface.

Table 1

Examples of «soft skills»*

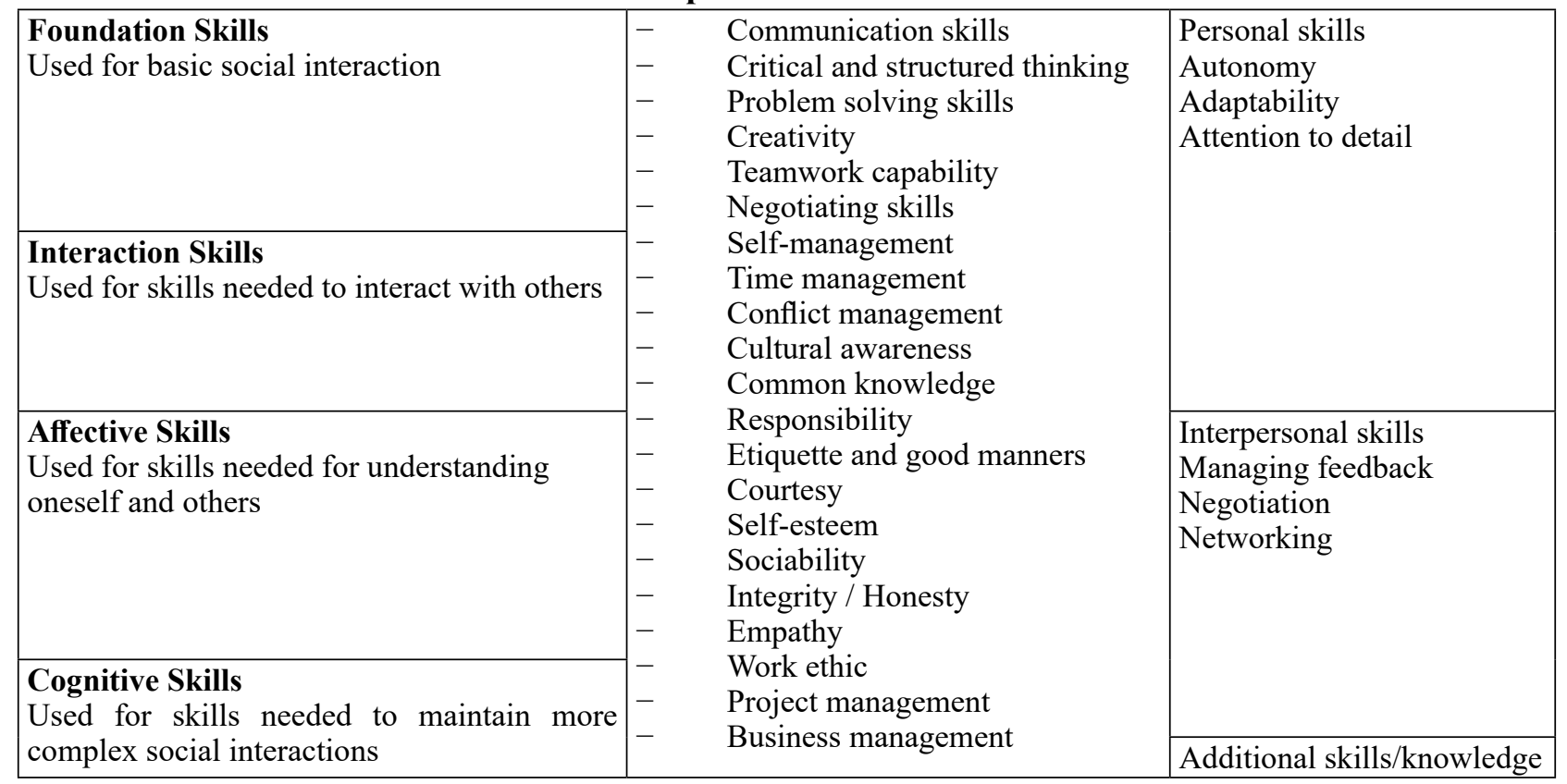

*formed according to (Canney and Byrne: 19-24, 2006; Schulz, 2008: 147) 


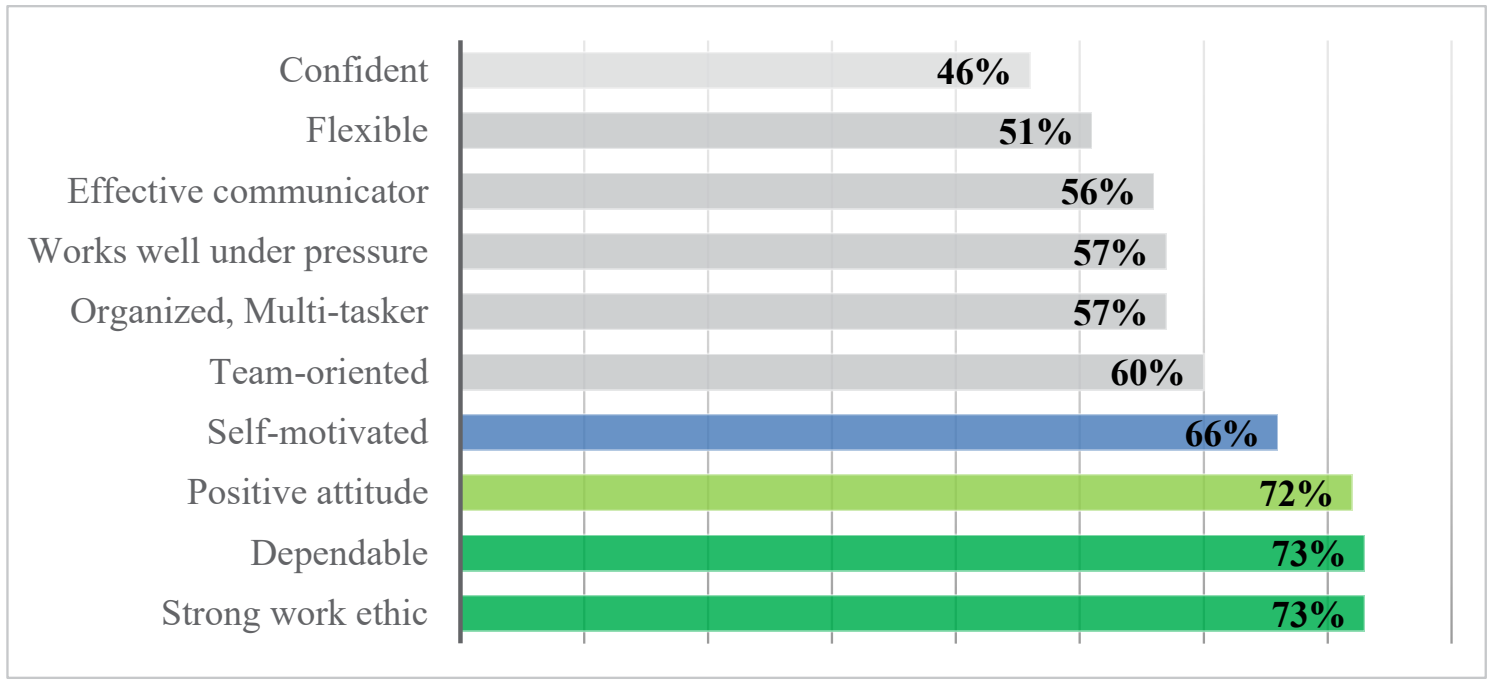

Figure 1. Most Sought-After «soft skills» According to Recruitment Managers and HR Professionals in the USA*

*formed according to (CareerBuilder, 2014)

Five essential communication skills should be formed when teaching ESL for business students. They are as follows:

1. Listening actively.

2. Influencing others.

3. Negotiating successfully.

4. Dealing with different communication styles.

5. Speaking clearly and concisely.

It is important to note that «soft skills» play a more prominent role in employability of young graduates in some industries than in others. Thus, in particular, trade and service tend to value «soft skills» much higher than the technical jobs.

The peculiarity of «soft skills» is that their application is not limited to the profession. They are constantly evolving in the course of their use in everyday life and at the workplace.

Implementation of the methodology of formation of «soft skills» should be based on the principles of communicative, intercultural, professional, individualized and socio-emotionally oriented learning, interdisciplinary links, etc.

Having analyzed foreign researches on "soft skills» development, the author's vision of the structure of interrelations between «soft skills» and school background, teacher's competence and efforts, student's environment, technical strengths and hard work is presented in fig. 2 .

Therefore, four basic types of «soft skills», namely communicative skills, interpersonal skills, problem solving skills and organizational skills have been distinguished.

The technology of formation of «soft skills» when teaching ESL provides a step-by-step construction of the learning process and includes the following stages:

- informing and motivating (formation of knowledge necessary for the formation of «soft skills» and forming a positive attitude to the activities);

- practical application (application of the gained knowledge and experience under new conditions for direct formation of «soft skills»);

- assessment (reflective analysis, self-control by students of the acquired knowledge and the formation of «soft skills», as well as their individual learning activities, control by the teacher).

Possible ways of introduction «soft skills» in ESL cource include the following:

- task based and problem-solving activities;

- group work involving discussions and debates (being helpful inside the classroom, students feel like they have a meaningful role within the group);

- delivering oral and poster presentations;

- role plays and dialogues;

- writing.

Based on the research and our own experience, we can identify five key qualities of a teacher who teaches English as second language to business students:

1. Leadership, so that the teacher should be a leader.

2. Communication, so that the teacher should be able to communicate.

3. Planning, so that the teacher should be able to plan ahead.

4. Adaptability, so that the teacher should be able to adapt to particular conditions. 
Dovhan L. Development of "soft skills" during ESL course for business students

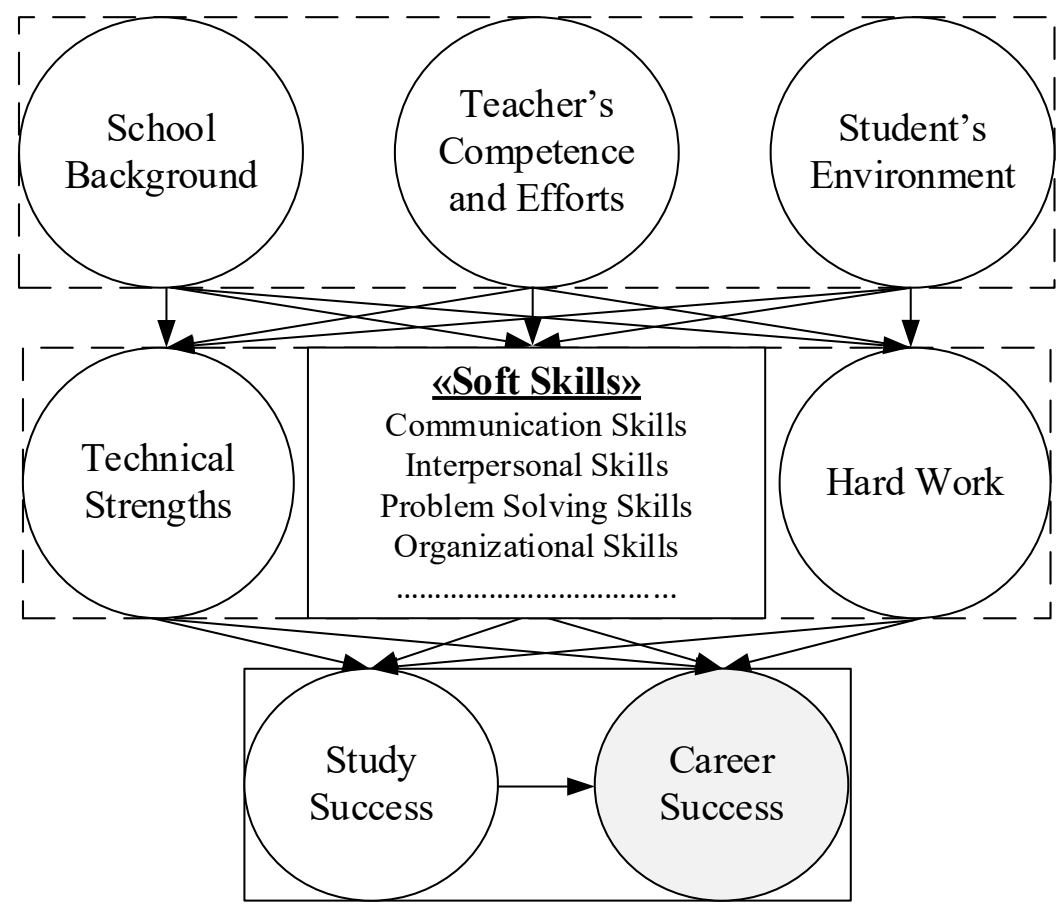

Figure 2. Outcomes of skills and efforts*

*formed by the author

5. Relationship building, so that the teacher should build his relationships with the students and teach them the same in relation to the peers.

Conclusions. Nowadays, fluency in English along with well-developed «soft skills», including the ability to discuss any issues in English, defend one's point of view, etc. is a powerful advantage in any competitive field of the labor market.

It can be recommended to implement «soft skills» development as an integral component of the ESL course that is largely based on communication and a lot of teaching practices and materials include working on students' «soft skills» and ability to communicate effectively. "Soft skills» like communication, work ethic, leadership, personal responsibility, and listening are all important for young adults. Modern methods and practices introducing «soft skills» in the ESL course will be discussed in detail in our further studies.

\section{REFERENCES}

1. Canney C., Byrne A. Evaluating Circle Time as a support to social skills development - reflections on a journey in school-based research. British Journal of Special Education. № 33 (1). P. 19-24

2. CareerBuilder. Overwhelming Majority of Companies Say «soft skills» Are Just as Important as Hard Skills, According to a New CareerBuilder Survey. 2014. Retrieved from: http://www.careerbuilder.com/share/aboutus/pressreleasesdetail. aspx?sd=4/10/2014\& id=pr817\&ed=12/31/2014 (Accessed on: 15.04.2021).

3. Collins English Dictionary. 2018. Retrieved from: https:/www.collinsdictionary.com/dictionary/english/soft-skills (Accessed on: 15.04.2021)

4. Coughlan S. Campaign puts economic value on «soft skills»»». 2015. Retrieved from: http://www.bbc.com/news/education-30802474 (Accessed on: 15.04.2021).

5. Lecis M., Fournet G., Cottin H., Buirel P., \& Ciobanu C. The importance of «soft skills» the importance of «soft skills» in the job market : an analysis of the «soft skills» demand by job, function and seniority level. 2020. Retrieved from: https://boost.rs/wp-content/uploads/2020/11/BOOSTRS_SOFT_SKILLS_STUDY_2020.pdf (Accessed on: 15.04.2021).

6. Klaus P. Communication breakdown. California Job Journal. 2010. № 28. P. 1-9.

7. Robles M. M. Executive perceptions of the top 10 soft skills needed in today's workplace. Business Communication Quarterly. 2012. № 75 (4), P. 453-465. doi: 10.1177/1080569912460400.

8. Schulz B. The Importance of «soft skills»: Education beyond Academic Knowledge. Journal of Language and Communication. 2011. Vol. 44, issue 32, P. 67-78.

9. Schulz B. The importance of «soft skills»: Education beyond academic knowledge. Nawa Journal of Communication. 2008. № 2 (1), pp. 146-154.

10. Watts M., Watts R. K. Developing «soft skills» in Students. 2008. Retrieved from: http://108.cgpublisher.com/proposals/64/index_html (Accessed on: 15.04.2021). 